\title{
"Parental leave rights in Italy: reconciling gender ideologies with the demands of
}

\section{Europeanization”}

Dr Roberta Guerrina, University of Surrey

Published in Busby, N. and G. James (2011) Families, Care-giving and Paid Work. Edward Elgar.

\section{Introduction}

Italy provides an interesting case study for the analysis of reconciliation policies in Europe. One of the first European states to ratify an extensive regulatory framework for the protection of working mothers and pregnant workers, it also has one of the worst track records when it comes to promoting equality of opportunities and women's access to employment. The level and depth of formal and informal discrimination against women has been widely documented, highlighting the pervasive nature of gender inequalities in the country. Berlusconi’s leadership style and the contentious nature of his appointments to key government positions, such as former glamour model Maria Cafagna as Equal Opportunities Minister, are indicative of the gender ideologies at work within state structures (Valentini 1997; Guerrina 2005; Hausmann, et al. 2009).

Mainstream public policy literature struggles to find an appropriate category for the Italian welfare regime. Focusing on the centrality of the family, it is often categorized as belonging to the Mediterranean model. However, vast regional differences in terms of economic performance, political participation and social norms produce a complex scenario for the analysis of social policies (Guadagnini and Donà 2007: 164; Velluti 2008). Jane Lewis’s (1992) typology of male breadwinner states perhaps provides a more useful way of thinking about the relationship between the function of care and social inequalities. Despite her recent shift away from this particular typology in favour of one based on the adult worker model (Lewis 2001; Giullari and Lewis 2005), the male breadwinner ideology remains relevant in the case of Italy.

It is against this backdrop that this chapter seeks to evaluate the emerging policy discourse on reconciliation between work and family life. Drawing on my earlier work (Guerrina 2005), this chapter will argue that reconciliation policies in Italy are a reflection of a particular gender ideology that revolves around the traditional family, which in turn is based on the dichotomization of the male breadwinner and female carer roles. This chapter sets out to 
unpack the assumptions underpinning dominant policy discourses on care, work-life balance, and women's employment. Trying to understand the overall impact of social policies on gender structures is inherently difficult. However, it is an important exercise as only by exposing the gendered nature of political narratives, can we then assess the extent to which substantive equality has been institutionalized.

This introductory section starts with a brief overview of important social trends in Italy, focusing in particular on the promotion of the traditional family and the implicit tensions between the function of care and paid work. This discussion is necessary as it frames the analysis of current reconciliation policies. This section is followed by an outline of historical development of reconciliation policies in the country. Here I will look at the institutionalization of equality norms within the Italian legal system, paying particular attention to the protection of mothers employed in the official labour market and the impact of Europeanization. The discussion presented here reveals the enduring importance of mothering as an ideology on the development of the equality agenda. These two introductory sections establish the main frames around which parental leave policies are negotiated and ratified in Italy. Section three will then look at recent debates about work-life balance, childcare and reconciliation. It will present the latest legal developments with a view of unpacking how they have been shaped by hegemonic gender discourses. In the final section, the chapter will conclude with an evaluation of the cumulative impact of current reconciliation policies on the reproduction of gender ideologies in Italy.

\section{The socio-economic context: enduring tensions between public and private roles}

The context within which debates about work-life balance, parental leave and reconciliation are being played out ultimately shapes the overall scope of the initiatives under discussion. A variety of social forces intervene in constructing hegemonic gender narratives in Italy and frame the development of parental leave and reconciliation policies: these include concerns about the survival of the traditional family, declining birth rates, as well as pressure from the EU to comply with European policies. Although these trends are highly interdependent and continue to shape policy discourse and the overall social policy agenda, this section is mainly concerned with how the dominant ideology of mothering and the traditional family support the Italian welfare state. This process is ultimately assumed to institutionalize long standing tensions between the function of care and paid work. 
The family, and its associated gender regime, is one of the core pillars of Italian society. The state's reliance on the family for the provision of welfare is so deeply entrenched within Italian society that it was supported by both ends of the political spectrum in the post-war settlement. However, this reliance on the family has led to concerns about the persistence of the double burden for working women and inequitable allocation of care work within the family (Gadagnini and Donà 2007: 164). Gender divisions of labour in the family have had a significant impact on women's access to paid employment. The tensions between employment policies (focused predominantly on rights), women's changing aspirations and the economic needs of contemporary families have accentuated the limits of reconciliation policies. This is particularly the case when these policies are characterized by a chronic lack of investment in public sector facilities and are heavily reliant on women's care role in the family (see below and see Stefán-Makay and Caporali 2010; Guadagnini and Doná 2007: 163).

The decline in Italian fertility rates, the impact of an ageing population on economic growth and increasing concern about the ability of the state to fulfil core welfare obligations have helped to bring the issue of reconciliation to the top of the policy agenda. In terms of fertility rates, there are a number of variables that appear to influence a family's decision of whether to have children, when to have children and how many children to have. A number of studies (see for instance: Del Boca et al. 2003; Castles 2003; Del Boca and Pasqua 2003) have identified time allocation and opportunity costs as two key variables in the decision-making process. Del Boca et al. (2003: 2) claim that cost-benefit structures are particularly important: 'in order to explain the observed negative relationship between fertility and income, economic models have introduced women's allocation of time decision and emphasized the opportunity costs of women's time'. In a nutshell, the 'opportunity costs of childbearing' has increased substantially in the last 30 years (Del Boca et al. 2003: 2). This is very important for the analysis of parental leave policies because the overall aim of this particular set of initiatives is to decrease the costs associated with women's participation in the official labour market. For Castels the relationship between women’s choices about fertility and reconciliation policies is clear:

... in a society in which the normatively assumed default position is that mothers will continue working after childbirth, it is a truism that fertility on any scale is largely a function of such policies being in place. But what that really means is that women will generally only choose to have children where flexible workplace arrangements are in 
place. This makes these policies prerequisites or preconditions of fertility rather than its consequences (2003: 221).

This points to a complex relationship between a social model that is heavily dependent upon the traditional family and state economic interests. One of the main concerns is thus to assess the effectiveness of structural measures aimed at promoting reconciliation between work and family life for women. Comparing the level of childcare provision in Italy with that available in other EU member states, it is clear that the state has done little to address the structural constraints that prevent women from making a full contribution to the official labour market (Aliaga 2005: 2; Del Boca et al. 2004: 2; Arpino et al. 2006).

\section{Policy trajectories: the institutionalization of the gender contract}

Recent developments in the field of reconciliation and parental leave have to be understood within the context of the institutionalization of equality norms within the Italian legal system. A number of legal measures have been adopted in the last five decades that outlaw direct discrimination. Many have been ratified under pressure from the EU, but the principles supporting formal equality are now well established within the Italian legal framework. Indirect and covert discrimination, however, are still widely practiced within the private sector of the economy.

The starting point for the analysis of women's position in society and the employment market has to be the 1947 Italian Constitution, which defined the post-war political and social settlement for the country. Article 29 and article 37 of the Constitution are particularly important for the analysis presented here as they reflect the dominant gender ideology. Article 29 places the traditional family at the heart of the state. Identified as a 'natural' institution, the Constitution secures the position of the family unit as the main provider of care. Article 37, on the other hand, seeks to protect the rights of women employed in the labour market whilst securing the position of mothers as primary carers:

The working woman has the same right and, for equal work, the same remuneration due to the man. Working conditions should permit the fulfilment of her essential family function and ensure adequate protection to the mother and the child. (Art. 37 of the 1947 Constitution - author’s translation) 
Taken together these two articles legitimized the hegemonic gender order and limited the potential scope of equality policies within the newly established Italian Republic (Donà 2006; Guerrina 2005; see also Smith’s discussion of Ireland's approach - in this collection).

The marked increase in women's labour market participation in the 1960s and the influence of feminist women in Parliament led to a number of radical policies seeking to establish a new gender contract. The most important for the analysis presented here is the 1971 Maternity Protection Act (Legge n. 1204/71). The result of much lobbying, this law was one of the main achievements of the women of the left. It also put Italy at the forefront of new initiatives to promote formal equality for working mothers. Based upon the 1950 provisions (Legge n. 860/1950), it regulated health and safety protection for pregnant workers and working mothers in the first year after childbirth. The scope of the legislation was farreaching. It set out a very radical agenda, including protection from dismissal, remuneration during maternity leave, as well as providing for breaks during the working day to enable mothers to continue breastfeeding (Guerrina 2005). At the point when this law was ratified, it was very innovative in the way it tackled the issue of working mothers' access to paid employment. However, the almost complete absence of men/fathers from the policy, ultimately reinforced gender divisions of labour in the family, and power hierarchies in the employment market. The result of this particular policy has been to increase the level of direct and indirect discrimination against women during the reproductive years, as employers became increasingly concerned about the costs associated with employing women (Valentini 1997).

This early law positioned Italy as a leader in the development of maternity protection policies in Europe. At first glance, the 1971 law appears to be a forerunner to the EU 1992 Pregnant Worker Directive, as it focused on health and safety, provided for minimum remuneration, and sought to maintain women's links to the official labour market. Interestingly though, fearing that the limitations of the Directive would put the Italian labour market/economy at a competitive disadvantage, the government was one of the most outspoken against the 1992 Pregnant Worker Directive (Guerrina 2005; Anon 1992). The Italian government’s position during the negotiations for the 1992 Pregnant Worker Directive is further indication that despite the presence of innovative and forward-looking policies, social and cultural change is slow to follow. Protecting the social function of care - or mothering - is deeply entrenched throughout the legislative portfolio: 'the Pregnant Worker Law Decree (n. 645/1996) according to Directive 92/85/EEC on the same issue, is more detailed regarding the 
safeguarding of pregnant women's health and the absolute ban on night work' (Longo and Sangiuliano 2007: 6). The message is clear, in Italy pregnant workers are protected in as far as maternity and women's role as carer needs to be supported and safeguarded. The main political and policy priorities are thus health and safety, largely focused on the protection of the unborn child (Longo and Sangiuliano 2007: 6). This reveals a deeply normative agenda operating at the political level whereby the need to protect the social function of mothering supersedes substantive equality (Guerrina 2005; Donà 2006; Longo and Sangiuliano 2007). The focus on women and mothers contradict the ethos of reconciliation policies, the purpose of which should be to challenge hegemonic gender narratives and divisions of labour in the family. Gobbo (2009) argues that the full implementation of the overarching objectives of these policies requires a paradigm shift. Clearly, women are directly affected by the scope and nature of the provisions available for the reconciliation of paid work and family life, but so are men, employers and political institutions. The impact of non-equality on fertility rates is an example of the need for a holistic approach to work-life balance (see Del Boca et al. 2003 for analysis of the opportunity costs of childbearing). The next section of this chapter will consider if and how European policies for the reconciliation between work and family life have changed the scope of national policies/laws and challenged the dominant gender ideology so evident in these early policies.

\section{Parental leave and reconciliation policies: the case of Italy}

Policy discourses about reconciliation, work-life balance and parental leave have an implicitly normative agenda, as they call for a revaluation or renewal of what is increasingly seen as an outdated and inefficient social model (Gobbo 2009). The literature on the adult worker model (Lewis 2001; Giullari and Lewis 2005) supports this analysis, arguing that the male breadwinner model is not only in decline but is being replaced by a new model of work-family time allocation. In this context, parental leave rights are located at a critical juncture in as far as their ultimate aim is to challenge gender hierarchies and divisions in the social function of care.

The shift towards the establishment of an adult worker model or a dual breadwinner family brings into question the position and role of men and women in the private, as well as the role of employers and the state in facilitating a shift in gender ideologies/divisions of labour (Gobbo 2009). In Italy, the 1991 Affirmative Action Law (Legge n. 125/1991) sought to formally address structural inequalities and obstacles to gender equality. It was therefore 
supposed to engender a change in discourse from formal to substantive equality (Gobbo 2009). However, it is unclear how this policy can accommodate this shift when the values attached to this policy area are in conflict with the hegemonic gender order - as articulated within the 1947 constitutional settlement

The concept of reconciliation entered the policy vocabulary relatively late in Italy and as a result of European commitments. The previous section highlighted the deeply normative character of equal rights legislation in Italy, whereby the principle of equality had been framed within the context of the dominant ideology of gender. The centrality of mothering and the traditional family within the post-war constitutional settlement is a clear indication that the 'sexual contract' is a fundamental pillar of the Italian social model (Pateman 1991; Gobbo 2009). The principles entrenched within the discourse on parental leave seek to challenge this dominant gender ideology; it is therefore worth considering the impact developments in this area will have on the core values supporting the Italian state structures. Four legislative texts ratified in the last decade are particularly important for any discussion about reconciliation between work and family life: the 2000 Act on Maternity and Paternity (Legge n. 53/2000); the Consolidated Act on the Protection of Maternity and Paternity (Decreto Legislativo 151/2001); the 2003 White Paper on Welfare (Legge Biagi); and the 2007 Law on Reconciliation between Work and Family Life. These legal measures have to be taken together in order to understand the cumulative impact on the dominant gender ideology at work in Italy.

The 2000 Act (Legge n. 53/2000) is wide ranging in scope, providing support for mothering, fathering, and work-life balance. It establishes a right for employees to take leave on the following grounds: (1) to fulfil the function of care; and (2) for professional development and training. It sets out regulations for remuneration during the leave period, and reasserts wellestablished norms about lengthy compulsory maternity leave (2 months prior to the birth and 3 months following the birth, though the split can now be negotiated to one month before birth and 4 months after birth). In terms of paternity leave, it expands the provisions introduced by the 1977 Equal Treatment Law (art. 7) (Legge n. 903/1977), thus increasing the opportunities for fathers to engage in the function of care. It is interesting at this point to note that the 1977 provisions established a right to paternity leave in cases of adoption or when the father has sole custody. Article 13 of the 2000 Act reiterates these norms, allowing fathers to be absent from work during the first 3 months of a child's life in case of maternal death, injury or abandonment. The language of both legal texts is one of exceptionalism, 
whereby the father is responsible for fulfilling the function of care when the mother is unwilling or unable to do so.

This Act also transposes EU guidelines and commitments on reconciliation between work and family life, specifically aimed at promoting greater balance for working parents. The focus on parental leave rights, flexibility and atypical working patterns, is supposed to facilitate a change in the social model and its associated gender division of labour (Gobbo 2009; Riva 2010). Perhaps the most important innovation introduced by this legislative measure is an imperative to change cultural attitudes towards work-life balance, including new concerns about human resources and employers' responsibilities. However, it is also clear that employers act as gatekeepers and their consistent opposition to reconciliation between work and family life remains the most significant obstacle to the renewal of the Italian social model (Gobbo 2009; Riva 2010).

Two issues arise from this initial analysis. Firstly, European policies provide the overall impetus for the expansion of the reconciliation agenda in Italy. The European equality agenda sets out the main objectives, the discourse and the overall strategy for the inclusion of reconciliation within the Italian policy framework. Secondly, the state remains committed to protecting the social function of mothering. The long period of compulsory leave is unaffected and the link between mothering and caring is not challenged.

Given the complexity of the issue at hand and in order to conform with European regulations, the Italian government sought to streamline all policies regulating maternity, paternity and parental leave, and more generally family-friendly policies under a single act in 2001: the Legislative Decree 151/2001 on a Unified Code of Regulations in the Matter of Maternity and Paternity (Velluti 2008; Longo and Sangiuliano 2007; Di Iorio 2006). Bringing together all previous legislation in the matter, including Law 1204/1971, it defines the key terms of reference and minimum provisions that employers have to comply with. Article 3 in particular, prohibits all discrimination against pregnant workers and workers who have recently given birth; as well as protecting against sex discrimination in matters of pay. Many of the areas covered reassert existing rights, including the focus on health and safety protection established by the Laws of 1971 and 2000. Specific reference is made to European regulations and standards relating to the protection of the health and safety of pregnant workers. Perhaps more interesting for the analysis presented are sections VI and VII that set out parental leave and leave for family reasons (i.e. sickness of children). In terms of parental 
leave it provides for 6 months parental leave, with the possibility of a 3-year extension at 30 per cent pay. Section VII also allows for remuneration to care for a sick dependant.

The Decree regulates in detail all norms relating to employment, maternity/pregnancy and, more generally, the family (Longo and Sangiuliano 2007: 8; Velluti 2008: 155). The stated aim of this Decree was to streamline the legal framework on reconciliation, however Velluti (2008: 155) finds that 'this measure ... was mainly programmatic describing in general terms the financial measures enacted'. As with previous provisions, the focus is on protecting - and preserving - the social function of mothering and ensuring that Italian law is aligned with the broader European priorities.

There is a significant degree of consistency and continuity - we could even talk of path dependency - in the overall aims of the policies discussed thus far. The White Paper on Welfare: Proposals for a Dynamic and Inclusive Society (Governo, 2003) was supposed to instigate a paradigm shift. Presented as a set of forward-looking proposals and developments, it was supposed to enable the establishment of a new social model based on equality, inclusion and solidarity. The proposal certainly helped to frame future debates. Looking at the changing nature of socio-economic challenges facing the country, including how to achieve a balance between welfare and liberalism (as promoted by globalization), and how to implement wider changes in the overall priorities of the European social dimension, it set out a reform agenda for the Italian state.

The White Paper and the ensuing Biagi Reform/Law (Legge n. 30/2003) are part of a labour market reform programme started in the late 1990s (Velluti 2008). This new legislative act sought to increase labour market flexibility in line with the Lisbon Strategy - which sought to promote women's economic activation and introduced the wider principle of flexicurity (see Beveridge and Velluti 2008). The stated objectives were to increase efficiency and modernize the Italian labour market. The unemployed, youths and women are identified as a priority. Whereas increasing flexibility and streamlining market structures are identified as a main strategy for facilitating the entry of these particular target groups into the labour market. In other words, this policy seeks to implement the flexicurity agenda, already well established at European level. Consistent with this aim, article 3h supports the introduction of atypical working patterns, particularly part-time work, to enable women with caring commitments to re-enter the labour market. Velluti produced a detailed gender assessment of this set of reforms. She concludes that gender is largely absent from the policy, in as far as it assumes that 'the measures will produce some positive impact on female employment without any 
strategic emphasis on a gendered understanding of the labour market or on a gender perspective on policy’ (2008: 151-2).

It is against this backdrop that the Law for the Reconciliation between Work and Family Life (Legge n. 247/2007) was ratified. Specifically seeking to implement the Lisbon Strategy it calls for a wholesale restructuring of the labour market, to increase flexibility, revise existing parental leave provisions - especially in terms of remuneration - and improving guarantees for equal treatment. Particularly worthy of notice is the focus on the issue of remuneration, which is supposed to encourage parents to take advantage of parental leave. This is the policy that makes the most explicit links to the European equality agenda. In particular it seeks to relate its provisions directly to the European (social) funds as well as the Lisbon targets and strategy. There is no doubt that the Lisbon targets frame the overall aims of this law and the entitlements entrenched within it.

The developments outlined above are clearly important as they mark a step change in overall policy trajectory. What is unclear is how the new policy objectives (i.e. increased female employment) can be reconciled with the overarching support for the traditional family also articulated within these initiatives. Italia 2020: Action Programme for the Women's Activation in the Labour Market (Governo 2009b) was supposed to break this hegemonic narrative. Recognising that previous policies (namely the 2000 Maternity and Paternity Law) failed to change the socio-economic behaviour of families, and on the back of a moderate increase in women's participation during 2008, this Action Programme seeks to consolidate the gains initiated by the Biagi Reform of 2003. The document is particularly keen to stress the growth in female employment. Greater labour market flexibility, improved provisions of care for children and the elderly are identified as the main explanatory variable for the increase in women's participation. What is interesting to note is the explicit recognition of the role of the market in facilitating women's access to employment, even if this shift has been the result of increased reliance on migrant women's work as carers. The narrative emerging from this document is heavily tied to the European policy agenda, including recognition of the low performance of the Italian labour market vis-à-vis the other member states, and the objectives of the Lisbon Agenda are clearly visible in the programme.

The document seeks to provide an explanation for the country's poor performance vis-à-vis women's access to paid work. Regional differences are put forward as one of the main explanatory variables. As noted previously, regional disparities are a recurrent theme in a number of policy documents as well as the wider academic literature. The data supports this 
particular reading of employment trends and practices, but it also fits into a well-established political narrative that seeks to maintain entrenched divisions between Northern, Central and Southern regions. In addition, concerns about ageing population and declining fertility rates provide the urgency for the development of new policies and practices that will help to facilitate women's participation in paid work. Calling for the modernization of the Italian social model to promote economic growth, will not necessarily produce a critique of dominant gender ideologies. Conversely, mothering and the traditional family remain largely untouched by the new policy discourse on reconciliation. The aim of this policy document is to facilitate the establishment of structures (such as childcare) that would enable working mothers to reconcile the demands of paid employment with those of mothering. Little is said about changing roles within the family, although fathers are encouraged to play a greater role in fulfilling the function of care.

Taken together, the main aim of these initiatives is to challenge the historical rigidity of the employment market to enhance women's access to paid work. Thus, the focus of attention has been women's participation in the public sphere, rather than men/fathers' lack of participation in the private/domestic sphere (Valentini 2010; Aliaga 2005; Del Boca et al. 2005). This overview also highlights a significant degree of continuity in the framing of reconciliation policies. There is, however a disjuncture between political/economic imperatives and dominant gender ideologies. Whereas concerns about declining birth rates and the ageing population provide the impetus for new policy initiatives, adherence to European guidelines whilst supporting the social function of mothering are the main frames of reference in the official policy document. The disciplining nature of gender norms ultimately shapes the policy portfolio in this area. Framing these initiatives through the lenses of the dominant gender ideology limits the effectiveness of the initiatives, as discrimination is often justified on the basis of the dominant ideology of mothering (Valentini 1997; 2010).

\section{Conclusions}

Looking at the development of parental leave and reconciliation policies in Italy raises important questions about the complex relationship between family structures, welfare regimes and the economic priorities of the country under consideration. All the policies evaluated here have articulated the need for the Italian economy to grow and develop, whilst sustaining the central role of the family within society. Women's mothering and caring is clearly articulated as a core pillar of society and, as such, something that needs to be 
supported and preserved. The position of this 'pillar' is accepted and is not subjected to a critical assessment of nature of the 'sexual contract' upon which it is based. There is also little evidence of a counter-discourse relating to how the traditional family fits a wider political/policy agenda. The power dynamics attached to this particular narrative about mothering are not questioned, and as a result the policies that emerge seek, at best, to enable women to continue to carry out this function whilst also engaging in the paid employment. The economic imperatives underpinning developments in parental leave and reconciliation policies should also not be underestimated as they are clearly the motivation for the shift in policy focus. Rather than engaging in a detailed assessment of the reasons why Italian women are choosing to have fewer children than they would deem ideal, the issue of the demographic transition is used to justify the implementation of the Lisbon targets. In the context of a political framework that continues to be very male dominated, and that is openly setting a normative agenda about women's position in society, politics and the economy, the continued reliance on European policies to engender a shift towards women-friendly employment policies indicates little or no meaningful engagement with the gender dimension of social and economic policies. Perhaps more worryingly, the oversight of a meaningful discussion about the necessity to strive for substantive equality (including a reallocation of responsibilities within the traditional family unit) is indicative of a political culture that uses equality as a means to an end (i.e. economic growth) rather than focusing on gender justice.

La Salandra's (2007) survey of women's employment and attitudes towards women’s employment found that social partners in Italy were particularly concerned about the issue of family-friendly policies. In particular, she found that the perceived rigidity of employment structures prevent men and women from developing a more balanced relationship between work and family. In particular, La Salandra (2007) and Sorrenti (2009) call for the establishment of new organisational cultures that do not disadvantage women who choose to have children. Yet the focus remains on women, rather than problematizing men's relationship with the private sphere. There is little evidence of a shift in this direction. Until this happens, reconciliation will remain an aspiration rather than a reality for the majority of Italian women. In this context, parental leave policies will therefore be little more than a tool at the hands of employers to develop arrangements to help women fulfil both the function of care and paid work. Without a change in attitude, however, these policies may well be used to justify further discrimination against women seeking to retain a formal relationship with the employment market during their reproductive years. 


\section{Bibliography}

Aliaga, C (2005) 'Gender Gaps in the Reconciliation between Work and Family Life' Eurostat Statistics in Focus - Population and Social Conditions, No. 4/2005

Anon (1992) 'Maternity Directive Gets Last Minute Go-Ahead', Crew Reports, Vol. 12 (10): 3-5.

Arpino, B, Pronzato, C. and Tavares, L (2010) 'All in the Family: Informal Childcare and Mothers’ Labour Market Participation. Institute for Social and Economic Research Working Paper, No. 2010-24.

Beveridge, F and Velluti, S. (eds) (2008) Gender and the Open Method of Coordination: Perspectives on Law, Governance and Equality in the EU. Ashgate, Aldershot.

Castels, F.G (2003) 'The World Turned Upside-Down: Below Replacement Fertility, Changing Preferences, and Family-Friendly Public Policy in 21 OECD Countries” Journal of European Social Policy, Vo. 13 (3): 209-27

Decreto Legslativo 11 April 2006, n.198 “Codice delle Pari Opportunita' tra Uomo e Donna, a Norma dell' Articolo 6 della Legge 28 Novembre 205, n. 246” Gazzetta Ufficiale n. 125 del 31 maggio 2006, Supplemento Ordinario n. 133

Decreto Legislativo 26 Marzo 2001, n.151 “Testo Unico delle Disposizioni Legislative in Materia di Tutela e Sostegno della Maternita’ e della parternita', a norma delle' articolo 15 della legge 8 Marzo 2000, n. 53” Gazzetta Ufficiale n. 96 del 26 Aprile 2001, Supplemento Ordinario 93

Del Boca, D.; Locatelli, M. And Vuri, D. (2004) 'Child Care Choices by Italian Households' IZA Discussion Paper Series, IZA DP No. 983. Available at: www.iza.org

Del Boca, D., Pasqual, S. And Pronzato, C. (2003) ‘Analyzing Women’s Employment and Fertility Rates in Europe: Differences and Similarities in Northern and Southern Europe' Centre for Household, Income, Labour and Demographic Economics, CHILD Working paper, published 29/05/2003 available at: http://www.child-centre.it/

Del Boca, D. and Vuri, D. (2006) 'The Mismatch between Employment and Child Care in Italy: The impact of Rationing”, Centre for Household, Income, Labour and Demographic Economics Working Paper, ChilD N. 08/2006. Available at: http://www.child-centre.it

Di Iorio, T. (2006) 'Le Politiche. Il Punto sui Congedi Parentali in Italia' in Gilli, D., Cardinali, V. And Scarpetti, G. (eds) Maternita', Lavoro, Discriminazioni. ISFOL, Rubettino: Roma. Also available at: www.lavoro.gov.it

Donà, A. (2006) Le pari opportunità. Condizione femminile in Italia e integrazione europea. Bari: Laterza.

Donà, A. (2009) 'Why is it so difficult to gender-mainstream the Italian Welfare State? The case of work-family reconciliation policies”. Paper presented at the European Conference on 
Politics and Gender, Queen’s University, Belfast (January 2009). Available at: http://www.essex.ac.uk/ecpr/standinggroups/documents/Dona.pdf

European Commission (2010) Flexible Working Time Arrangements and Gender Equality: A comparative Study of 30 Countries. Luxembourg: Publications Office of the European Union.

Giullari, S. and Lewis, J. (2005) 'The Adult Worker Model Family, Gender Equality and Care: The Serarch for New Policy Principles, and the Possibilities and Problems of a Capabilities Approach’ Social Policy And Development Programme Paper, No. 19 (April 2005), United Nations Research Institute

Gobbi, D. (2009) "Concliare Famiglia e Lavoro: un Aiuto dal Fondi Articolo 9 della Legge 53/2000’ Collana Focus Isfol, n. 2009/2. Available at: www.isfol.it

Governo Italiano, Presidenza del Consiglio dei Ministri (2009c) “Protocollo D’Intesa tra il Ministro per la Pubblica Amministrazione e L’Innovazione e Il Ministro per le Pari Opportunita' e Il sottosegretario Delegato per le Politiche della Famiglia per la Realizzazione di Nidi Aziendali Presso le Pubbliche Amministrazioni”; available at:

http://www.innovazionepa.gov.it/

Governo Italiano, Ministero del Lavoro, della Salute e dell politiche Sociali, (2009b) Italia 2020: Programme di Azioni per l'Inclusione delle Donne ne Mercato del Lavoro, 1

December 2009

Governo Italiano, Ministero del Lavoro, della Salute e delle politiche Sociali (2003) Libro Bianco sul Welfare - Proposte per Una Societa’ Dinamice e Solidale. Roma, Febbraio 2003

Guadagnini, M and Donà, A. (2007) ‘Women’s Policy Machinery in Italy between European Pressure and Domestic Constraints’ in Outshoorn, J. and J. Kantola (eds) Changing State Feminism. Palgrave.

Guerrina, R. (2005) Mothering the Union: Manchester University Press

Hausmann, R, Tyson, L and Zahidi, S. (2009) Global Gender Gap Report, 2009. World Economic Forum, Switzerland.

La Salandra, M (2007) “Gender and Career Development - Italy” EIROnline Publication Date: 18/05/2007; available at: http://eurofound.europa.eu/ (accessed December 2010)

Legge 24 Dicwembre 2007, n. 247 “Norme di attuazione del Protocollo del 23 Luglio 2007 su previdenza, lavoro e pometitivita' per favorire l' equita' e la crescita sostenibili, nonch' ulteriori norme in material di lavoro e previdenza sociale', Gazzetta Ufficiale, n. 301 del 29 Dicember 2007

Legge 14 Febbraio 2003, N. 30 "Delega al Governo in material di occupazione e mercatop del lavoro”, Gazzetta Ufficiale, n. 42 del 26 Febbraio 2003

Legge 8 Marzo 2000, N. 52 “Disposizioni per il S0stegno della Maternita' e della Parternita', per il Diritto alla cura e all formazione e per il coordinamento dei tempi delle Citta’' Gazzetta Ufficiale, n. 60 del 13 Marzo 2000. 
Legge 30 Dicember1971, No. 1204 “Tutela delle Lavoratrici Madri” Gazzetta Ufficiale, n. 14 del 18 Gennaio 1972

Legge 9 Dicembre 1977, No. 903 "Parità di Trattamento tra Uomini e Donne in Materia di Lavoro”, Gazzetta Ufficiale, n. 343 del 17 Dicembre 1977

Legge 26 Agosto 1950, N. 860 ‘Tutela Fisica ed Economica delle Lavoratrici Madri’, Gazzetta Ufficiale, n. 235 del 3 Novembre 1950

Lewis, J (2001) “The Decline of the Male Breadwinner Model: Implications for Work and Care” Social Politics, Vol. 8(2):152-68

Lewis, J. (1992) 'Gender and the Development of Welfare Regimes' Journal of European Social Policy, Vol. 2 (3)

Lombardo, E. and Meier, P (2008) 'Framing Gender Equality in the European Union Political Discourse” Social Politics: International Studies in Gender, State and Society, Vol. 15 (1): $101-29$

Longo, Valentina and Sangiuliano, Maria, (2007) 'Issue Histories Italy: Series of Timelines of Policy Debates'. QUING Project: Institute for Human Sciences (IWM), available at: http: www.quing.eu/files/results/ih_italy.pdf

Pateman, C. (1991) The Sexual Contract. Polity Press, Cambridge and Oxford

Riva, E. (2010) 'Lavoro e tempi di vita, l' articolo scomparso' ingenere: donne e Uomini per la Societa’ che Cambia, Newsletter. Available at: http://www.ingenere.it/articoli/lavoro-etempi-di-vita-larticolo-scomparso

Sorrenti, R (2009) 'Diversity Management \& Work-Family Balance, vie possibili tra equilibrio personal e competitivita' aziendale' in Panetta, C. and Romita, MT (eds) Gender diversity e strategie manageriali per la valorizzazione delle differenze. Interviste HRC Academy a donne-manager di successo. Franco Angeli.

Stefán-Makay, Z and Caporali, A. (2010) “Interconnections between Mothers’ Working Patterns after Childbirth and Fertility Intentions. A comparison between France, Hungary and Italy. Paper presented at the European Population Conference, 1-4 September 2010.

Available at: http://epc2010.princeton.edu/

Valentini, C. (1997) Le Donne Fanno Paura. Milano: Il Saggiatore.

Velluti, S. (2008) "Gender Equality and Mainstreaming in the Re-articulation of Labour Market Policies in Denmark and Italy' in Beveridge, F and Velluti, S. (eds) Gender and the Open Method of Coordination: Perspectives on Law, Governance and Equality in the EU. Ashgate. 